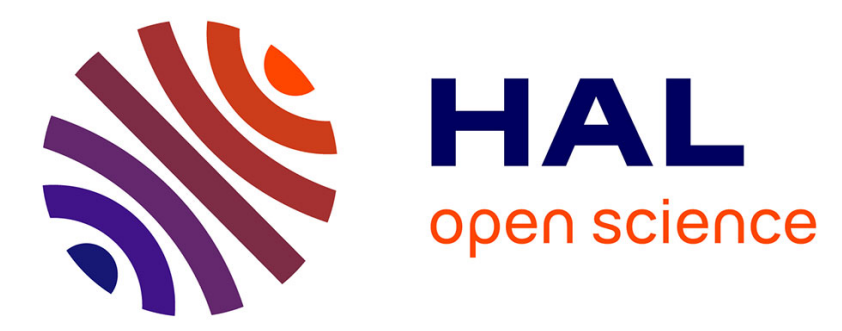

\title{
A long term experiment of integrated control of nematode parasitism in Creole goats
}

Jean-Luc Blaes, Nathalie Mandonnet, Rémy R. Arquet, Maurice Mahieu

\section{To cite this version:}

Jean-Luc Blaes, Nathalie Mandonnet, Rémy R. Arquet, Maurice Mahieu. A long term experiment of integrated control of nematode parasitism in Creole goats. Advances in Animal Biosciences, 2010, 1 (2), pp.413-414. 10.1017/S2040470010000403 . hal-02653438

\section{HAL Id: hal-02653438 \\ https://hal.inrae.fr/hal-02653438}

Submitted on 29 May 2020

HAL is a multi-disciplinary open access archive for the deposit and dissemination of scientific research documents, whether they are published or not. The documents may come from teaching and research institutions in France or abroad, or from public or private research centers.
L'archive ouverte pluridisciplinaire HAL, est destinée au dépôt et à la diffusion de documents scientifiques de niveau recherche, publiés ou non, émanant des établissements d'enseignement et de recherche français ou étrangers, des laboratoires publics ou privés. 
and PCV values were found in goats without an apparent parasitic infection, an occasional and a $2+$ degree of parasitic infection. Lower mean serum $\mathrm{Cu}$ concentrations were found in sheep without evidence of parasitic infections and in goats with both $1+$ and $4+$ degree of mixed infections. Twenty-five to $37 \%$ of parasitized sheep and goats had serum $\mathrm{Cu}\left(<0.5 \mathrm{mg} \mathrm{L}^{-1}\right)$ and $\mathrm{P}\left(<40 \mathrm{mg} \mathrm{L}^{-1}\right)$ Below Critical Levels (BCL).

\title{
Conclusions
}

The degree of mixed parasitic infections was somewhat related to the lowered $\mathrm{Hb}$ and PCV mean values and serum Cu concentrations more so in goats than in sheep from swayback prone farms. Both regular treatment for parasitism and mineral supplementation would impact positively on the growth, health and productivity of sheep and goats of Central Trinidad.

\section{Acknowledgements}

Special thanks are due to Drs. W. Harper and J. De Freitas, Messrs. N. Persad, F. Neckles, S. Deosaran, W. Christmas, J. Gangadeen, B. Lauckner, $\mathrm{M}$. Jones and P. Antoine. We are deeply indebted to our local farmers who allowed us access to their animals to complete this survey.

\section{Reference}

Mohammed A 1999. The mineral status and haematological Values of sheep and goats with reference to swayback in Trinidad. PhD, the Univ. of the West Indies.

\section{A long term experiment of integrated control of nematode parasitism in Creole goats}

\author{
Jean-Luc Blaes, Nathalie Mandonnet ${ }^{\dagger}$, Rémy Arquet and Maurice Mahieu
}

INRA UR143, Unité de Recherches Zootechniques, 97170 Petit-Bourg, Guadeloupe, France

\section{Introduction}

Infection with gastro-intestinal nematodes (GIN) is one of the most prevalent diseases affecting small ruminants in the tropics. Mixed grazing between sheep and cattle reduces infection of the small ruminants and improves growth performances (Mahieu et al., 1997). Also, it is possible to select Creole goats on resistance to GIN during the post weaning growth and the periparturient period (Mandonnet et al., 2006). This study presents the potential benefits of combining these two control methods.

\section{Material and methods}

Four different herds of Creole goats were used for the experimentation at INRA-Gardel in Guadeloupe: two herds grazing alone, one with average genetic level $(\mathrm{R} 0)$ and the other resistant $(\mathrm{R}+)$ and two herds grazing with heifers, one with average genetic level (M0) and the other resistant $(\mathrm{M}+)$. The genetic index for the $\mathrm{R} 0$ and $\mathrm{M} 0$ herds was +0.08 and -0.12 for the herds $\mathrm{R}+$ and $\mathrm{M}+$. That represented 0.53 genetic standard deviation of faecal egg count (FEC) criterion. Each herd was grazing on the same paddock throughout the experimentation. The stocking rate was set to around $500 \mathrm{~kg}^{0,75} / \mathrm{ha}$ for the $\mathrm{R}+$ and $\mathrm{RO}$ herds, and to $250 \mathrm{~kg}^{0,75} / \mathrm{ha}$ (goats) $+250 \mathrm{~kg}^{0,75} / \mathrm{ha} \mathrm{f(cattle)} \mathrm{for} \mathrm{the} \mathrm{M+} \mathrm{and}$ $\mathrm{M} 0$ herds at the beginning of each cohort. Each herd was composed of pregnant and suckling goats, which allowed the comparison between dry and lactating dry goats.

Doe faecal samples were collected at weeks 4 and 6 after kidding. FEC were estimated using a McMaster method. The individual parasitic level was estimated with the mean of FEC at week 4 and 6 after kidding.

Data were collected beginning in 2006 corresponding to 12 cohorts and 435 does. The effects of the explicative variables (resistance level, grazing mode, physiological status, litter size, year, season, and their significant first-order interactions) were studied using the GLM procedure of SAS software release 8.1 (SAS institute Inc., 1999-2000). FEC data were cubic-root transformed before analysis to normalize the distribution. The results were then back transformed (geometrical means).

\section{Results and discussion}

Lactating does had a significantly higher FEC than dry does at each sampling point $(P<0.0001)$ except for three cohorts where the difference was not significant. Moreover, the litter size had a significant effect on the infection level: does with a multiple litter were significantly more infected than does with a single one $(P<0.05)$. These results are similar to those reported by Mandonnet et al. (2005). The FEC of the

\footnotetext{
† E-mail: Nathalie.Mandonnet@antilles.inra.fr
} 
different herds is shown in Figure 1 with the confidence interval of the mean. The FEC of the non resistant herd grazing with heifers (M0) is significantly higher than the FEC of the 2 resistant herds $(M+$ and $R+)$. The effect of selection improves the ability of the does to control parasite infection. The effect of the grazing mode was not significant enough to explain the difference between the herds for the FEC.

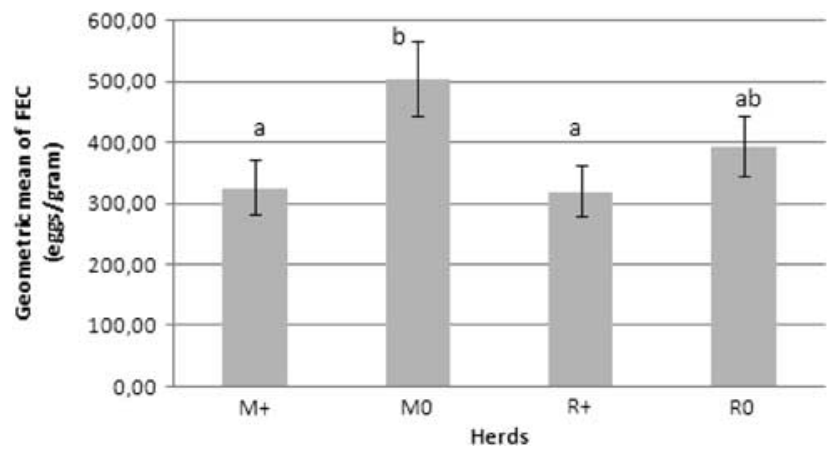

Figure 1 Evolution of the geometric mean of FEC (eggs/gram) (mean of FEC at weeks 4 and 6 after kidding) Columns topped by different letters differ significantly $(P<0.05)$.

\title{
Conclusion and perspectives
}

These first results suggest a better resistance to $\mathrm{GIN}$ of the resistant-selected herds $(\mathrm{M}+$ and $\mathrm{R}+$ ) compared to the non resistant herd grazing with heifers (M0). However, doe infection is one aspect of the comparison. The performance of the herds will also be studied using other parameters like PCV and EOSI to assess the parasite infection characteristics. The kid average daily gain (ADG) will allow estimating the milk output of the does (ADG 10 to 30 day) and the kid growth potential (ADG 30 to 70 day). The estimates of the litter weight at weaning and of the doe and cattle weight variations will allow comparing the productivity of the four herds.

\section{Aknowledgments}

The authors thanks the European Community (FEOGA) and "La Région Guadeloupe" for their financial support.

H. Varo and L. Abinne-Molza from parasitological laboratory and the small ruminant team in Gardel for their technical assistance are also warmly thanked.

\section{References}

Mahieu M, Aumont G, Michaux Y, Alexandre G, Archimède H and Boval M 1997. INRA Productions Animales 10 (1), 55-65.

Mandonnet N, Bachand M, Mahieu M, Arquet R, Baudron F and Abinne-Molza L 2005. Veterinary Parasitology 134, $249-259$.

Mandonnet N, Menendez-Buxadera A, Arquet R, Mahieu M, Bachand M and Aumont G 2006. Animal Science 82, $283-287$.

doi:10.1017/S2040470010000415

\section{Morphological characterization and breeding system identification of local sheep breeds in Niger}

\author{
Bello Abina Abdoul Karim ${ }^{1 \dagger}$, Pr. Djemali M’Naouer ${ }^{1}$ and Dr Augustine Ayantundé ${ }^{2}$ \\ ${ }^{1}$ Institut National Agronomique de Tunis (INAT) avenue Charles Nicoles 1002 Tunis-Tunisie; ${ }^{2}$ International Livestock Researche Institut (ILRI-Niger)/ICRISAT-Niger
}

In Niger, livestock breeding is the second rural population activity, contributing $12 \%$ to the national GDP and $40 \%$ to agricultural production. The national livestock include a large range of domestic animal species among which ovine species, which represent $20 \%$ of this livestock. These ovine resources constitute an important genetic variety source, well adapted to the rough environmental conditions of Niger. However, these genetic resources are generally very little known and subjected to inappropriate breeding practices by their holders (shepherds and farmers). These factors contribute to reducing their productive and reproductive potential and threaten the integrity of some native breeds.

\footnotetext{
† E-mail: baak_ne@yahoo.fr
} 